\title{
Diskrepansi Nilai CRP dan LED pada Fase Akut Penyakit Kawasaki
}

Najib Advani, Lucyana Alim Santoso

Departemen Ilmu Kesehatan Anak Fakultas Kedokteran Universitas Indonesia Rumah Sakit Dr. Cipto Mangunkusumo, Jakarta

Latar belakang. Dasar diagnosis penyakit Kawasaki (PK) yang ditetapkan oleh konsensus American Heart Association (AHA) 2004 dan 2017 berdasarkan gejala dan tanda klinis, serta ditunjang oleh pemeriksaan laboratorium, di antaranya reaktan fase akut, seperti CRP ( $C$ reactive protein) dan LED (laju endap darah) yang umumnya meningkat pada fase akut. Penelitian sebelumnya mendapatkan adanya perbedaan nilai (diskrepansi) antara keduanya.

Tujuan. Untuk mengetahui apakah pada fase akut PK cukup diperiksa CRP atau LED atau keduanya.

Metode. Penelitian retrospektif yang melibatkan 1163 subjek PK secara konsekutif selama 1 April 2000 sampai dengan 31 Mei 2017.

Terdapat 741 subjek yang memenuhi syarat kelengkapan semua data. Nilai potong yang digunakan untuk peningkatan CRP adalah $>30 \mathrm{mg} / \mathrm{dl}$, dan LED >40 mm.

Hasil. Terdapat dikrepansi antara nilai CRP dan LED pada 30,8\% subjek yang artinya nilai CRP meningkat sedangkan LED normal atau sebaliknya.

Kesimpulan. C reactive protein maupun LED perlu diperiksa bersamaan pada fase akut PK. Sari Pediatri 2018;19(6):307-10

Kata kunci: penyakit Kawasaki, CRP, LED

\section{Discrepency between CRP and ESR Values at Acute Stage of Kawasaki Disease}

Najib Advani, Lucyana Alim Santoso

Background. The diagnosis of Kawasaki disease (KD) according to the AHA statements 2004 and 2017 is based on clinical findings. Laboratory tests, especially acute phase reactans such as CRP and ESR are useful to support the diagnosis. The degree of elevation of ESR (erythrocyte sedimentation rate) and CRP (C reactive protein) may be discrepant as shown by a previous study.

Objective. To determine whether it is necessary to examine both CRP and ESR or either of them at acute stage of Kawasaki disease Methods. We did a retrospective study on 1163 subjects with KD which were taken consecutively from 1 st April 2000 untill 31 st May 2017. There were 741 subjects with complete medical records. We used the cut off point of CRP > 30 mg/dL, and ESR > 40 $\mathrm{mm}$ to be categorized as elevated.

Results. There were 30.8\% subjects with discrepancy between their CRP and ESR results, which means elevated CRP with normal ESR or vice versa.

Conclusion. Both CRP and ESR need to be examined at acute stage of KD. Sari Pediatri 2018;19(6):307-10

Keywords: Kawasaki disease, CRP, ESR

Alamat korespondensi: DR. dr. Najib Advani, SpA(K), MMed (Paed). Departemen Ilmu Kesehatan Anak Fakultas Kedokteran Universitas Indonesia, Jakarta. Email:najib.advani@gmail.com 
$\mathrm{P}$ enyakit Kawasaki (PK) adalah suatu kondisi akut pada anak yang ditandai dengan demam, ruam polimorfik, injeksi konjungtiva, perubahan mukosa mulut, eritema telapak tangan dan kaki, serta limfadenopati servikal. ${ }^{1}$ Etiologi PK belum diketahui, tetapi terdapat vaskulitis sistemik. Terapi utama saat ini adalah pemberian imunoglobulin intravena disertai aspirin oral. Berbagai penanda inflamasi atau reaktan fase akut akan meningkat pada $\mathrm{PK}$, di antaranya $C$-reactive protein (CRP) dan laju endap darah (LED). ${ }^{2}$ Berdasarkan pedoman AHA (American Heart Association) tahun 2004 dan 2017, kedua reaktan fase akut tersebut disarankan untuk diperiksa pada pasien dengan kecurigaan PK. ${ }^{3,4}$

Fisiologi terbentuknya LED dan CRP berbeda. Laju endap darah memiliki waktu paruh yang lebih panjang dibanding CRP. Oleh karena itu, LED lebih bermanfaat untuk menandakan kondisi inflamasi kronik dan dapat bertahan hingga beberapa hari atau minggu setelah inflamasi teratasi. ${ }^{5}$ Di sisi lain, CRP lebih bermanfaat untuk diagnosis dan pemantauan respon terapi pada kondisi akut karena kadarnya meningkat dalam 24 jam, ${ }^{6}$ memiliki waktu paruh yang singkat, dan nilainya kembali normal dalam 3-7 hari pasca jejas jaringan. ${ }^{7}$

Suatu penelitian menunjukkan bahwa diskrepansi (perbedaan nilai atau inkonsistensi) antara CRP dan LED dijumpai pada $44 \%$ kasus PK. ${ }^{2}$ Oleh sebab itu, pengukuran keduanya dianjurkan saat presentasi awal penyakit. ${ }^{7}$ Dikatakan bahwa kemungkinan diagnosis PK kecil jika LED, CRP, dan hitung trombosit normal sampai hari ke-7 awitan demam. ${ }^{3,4}$ Laju endap darah merupakan prediktor yang baik untuk diagnosis $\mathrm{PK}$, memiliki sensitivitas $94 \%$, dan spesifisitas $83,3 \% .^{8}$ Nilai CRP akan kembali normal dalam beberapa hari setelah terapi PK. Terapi immunoglobulin intravena untuk PK akan meningkatkan LED sehingga CRP lebih bermanfaat untuk monitoring terapi. ${ }^{6,7,9}$ Penelitian diskrepansi CRP dan LED untuk pasien PK di Indonesia belum ada. Penelitian ini ditujukan untuk menjawab pertanyaan apakah pada populasi pasien PK cukup pemeriksaan LED atau CRP atau keduanya.

\section{Metode}

Penelitian ini merupakan penelitian retrospektif potong lintang yang dikerjakan pada 741 pasien
PK yang direkrut secara konsekutif selama 1 April 2000 - 31 Mei 2017. Subjek merupakan pasien dari beberapa rumah sakit di Jabodetabek. Semua pasien ditangani oleh penulis sendiri sejak awal. Diagnosis PK komplit ditegakkan secara klinis jika ditemukan 5 dari 6 kriteria, yaitu demam minimal 5 hari, konjungtivitis bilateral (tanpa eksudat), bibir/lidah merah, pembesaran kelenjar getah bening servikal, ruam polimorfik, dan eritema palmar/plantar. ${ }^{3.4}$ Diagnosis PK inkomplit ditegakkan jika terdapat kurang dari 5 kriteria, tetapi dijumpai kelainan arteri koroner pada ekokardiografi. ${ }^{3}$ Subjek adalah pasien PK pada fase akut dan dieksklusi apabila data tidak lengkap. Data CRP dan LED disajikan berupa data kategorik dengan nilai potong CRP $>30 \mathrm{mg} / \mathrm{L}$, dan LED $>40 \mathrm{~mm} /$ jam yang sesuai untuk diagnosis PK fase akut. ${ }^{3,4}$ Diskrepansi didefinisikan sebagai ketidaksesuaian atau inkonsistensi antara nilai CRP dan LED, misalnya CRP tinggi namun LED rendah, atau sebaliknya. Data diolah dengan SPSS versi 20.0.

\section{Hasil}

Jumlah subjek PK selama April 2000-Mei 2017 adalah 1163 anak. Dari jumlah tersebut terdapat 741 subjek yang memenuhi kriteria kelengkapan data, terdiri dari 284 (38,3\%) perempuan dan 457 (61,7\%) lelaki. Karakteristik pasien tertera pada Tabel 1. Sebaran usia subjek terbanyak adalah untuk usia $<5$ tahun, yaitu $590(79,6 \%)$, sedangkan usia 5-10 tahun 139 $(18,8 \%)$, dan usia $>10$ tahun $12(1,6 \%)$, (Tabel 3$)$. Dari 741 subjek didapatkan peningkatan LED 610 (82,3\%) dan peningkatan CRP pada $514(69,4 \%)$ pasien. Jumlah diskrepansi didapatkan 228 (30,8\%) subjek (Tabel 2). Pasien dengan diskrepansi CRP dan LED datang dengan rerata demam 9 hari (SD 6 hari), dibandingkan dengan tanpa diskrepansi datang saat demam 8,5 hari (SD 4 hari).

Persentase diskrepansi lebih banyak dijumpai pada kelompok pasien dengan gejala inkomplit, yaitu 72 (35\%) pasien dibandingkan kelompok komplit 156 (29\%), tetapi perbedaan keduanya tidak bermakna secara statistik $(\mathrm{p}=0,13)$. Diskrepansi yang dijumpai pada pasien PK tanpa dilatasi koroner 31\%, dan pada PK dengan dilatasi koroner 30\% yang secara statistik tidak bermakna $(\mathrm{p}=0,783)$. Distribusi diskrepansi tertera pada Tabel 2 dan perbandingan berdasarkan kelompok usia tertera pada Tabel 3. 
Tabel 1. Karakteristik pasien $(\mathrm{n}=741)$

\begin{tabular}{lc}
\hline Variabel & Jumlah \\
\hline Jenis kelamin & \\
Perempuan, n (\%) & $284(38,3)$ \\
Laki-laki, n (\%) & $457(61,7)$ \\
Usia, rerata (SD) bulan & $36,9(29)$ \\
Lama demam, median (min-maks) hari & $7(1-16)$ \\
Presentasi gejala & \\
Komplit & $536(72,3)$ \\
Inkomplit & $205(27,7)$ \\
Hb, rerata (SD) g/dL & $10,9(1,28)$ \\
Leukosit, median (min-maks), sel /uL & $15.400(1200-59000)$ \\
CRP (mg/L), median (min-maks) & $74,5(0,1-449)$ \\
LED (mm/jam), rerata (SD) & $71(37,8)$ \\
Dilatasi koroner & \\
Ya & $192(28)$ \\
Tidak & $549(72)$ \\
\hline
\end{tabular}

Tabel 2. Persentasi diskrepansi antara CRP dan LED pada pasien Kawasaki

\begin{tabular}{ll}
\hline Kategori $(\mathrm{n}=805)$ & Jumlah $(\mathrm{n}, \%)$ \\
\hline LED & \\
Meningkat $(>40 \mathrm{~mm} / \mathrm{jam})$ & $610(82,3)$ \\
Tidak meningkat & $131(17,7)$ \\
CRP & \\
Meningkat $(>30 \mathrm{mg} / \mathrm{L})$ & $514(69,4)$ \\
Tidak meningkat & $227(30,7)$ \\
Diskrepansi & $228(30,8)$ \\
Tidak diskrepansi & $513(69,2)$ \\
\hline
\end{tabular}

Tabel 3. Diskrepansi CRP dan LED berdasarkan kelompok usia

\begin{tabular}{lcc}
\hline Kelompok usia (tahun) & Diskrepansi & Tidak diskrepansi \\
\hline$<5$ & $183(31)$ & $407(69)$ \\
$5-10$ & $41(29,5)$ & $98(70,5)$ \\
$>10$ & $4(33,3)$ & $8(66,7)$ \\
\hline
\end{tabular}

\section{Pembahasan}

Meskipun diagnosis PK terutama didasarkan pada gejala klinis, pemeriksaan kadar LED dan CRP biasanya dilakukan untuk membantu menegakkan diagnosis. Jika terdapat peningkatan nilai salah satu atau keduanya, hal itu akan menyokong diagnosis. Jika CRP, LED, dan hitung trombosit tetap sampai hari ke-7 awitan demam, diagnosis PK perlu diragukan., ${ }^{3,4}$

Dari segi biaya, jika diperiksa LED saja akan lebih murah dibandingkan CRP. Penelitian ini membuktikan adanya diskrepansi yang cukup besar antara nilai CRP dan LED (rerata sekitar 30\%) sehingga keduanya tetap perlu diperiksa secara bersamaan. Hasil penelitian ini sesuai dengan penelitian sebelumnya bahwa terdapat diskrepansi yang cukup besar pada nilai CRP dan LED pada fase akut PK. ${ }^{2}$ Pemeriksaan salah satu saja dapat menimbulkan keraguan atau salah tafsir.

Pemeriksaan CRP mungkin dapat diabaikan jika gejala dan tanda klinis PK komplit dan jelas dan hasil pemeriksaan LED meningkat signifikan, serta keterbatasan biaya. Sebaliknya, untuk menilai kemajuan terapi setelah pemberian immunoglobulin, pemeriksaan CRP jelas lebih unggul. Saat inflamasi mencapai puncaknya, kadar CRP dan/atau LED mencapai nilai tertinggi dan berangsur turun. Setelah pemberian imunoglobulin kadar CRP akan cepat menurun dalam beberapa hari, sedangkan kadar LED justru meningkat. ${ }^{7}$ Laju endap darah tidak bermanfaat untuk monitoring terapi karena akan meningkat akibat interaksi dengan fibrinogen, yang juga merupakan reaktan fase akut utama dan merupakan protein asimetris yang sangat memengaruhi nilai LED. ${ }^{7,10}$ Jika secara klinis setelah terapi pasien sudah membaik dan tanda-tanda inflamasi sudah reda atau hilang, pemeriksaan ulang reaktan fase akut bukanlah merupakan keharusan. 
Berdasarkan penelitian di Indonesia dilaporkan bahwa sekitar 7\% pasien PK tidak responsif (non responder) terhadap pemberian imunoglobulin $(2 \mathrm{~g} / \mathrm{kgBB})$, dengan definisi demam menetap 48 jam setelah pemberian imunoglobulin selesai. ${ }^{11}$ Pada kasus seperti ini, pemeriksaan CRP setelah pemberian imunoglobulin bermanfaat untuk menilai derajat inflamasi dengan membandingkan dengan nilai sebelum terapi. Pemeriksaan CRP ulang diperlukan jika setelah 36-48 jam pemberian immunoglobulin demam belum reda. ${ }^{4}$ Pada kondisi ini, peran CRP sangat penting dan tidak dapat digantikan oleh LED. Dalam kondisi normal, CRP akan cepat menurun. Jika setelah 36-48 jam demam menetap, dan tidak ada penurunan kadar CRP, sedangkan tidak ada faktor inflamasi atau infeksi selain PK, mungkin perlu dipertimbangkan pemberian ulang imunoglobulin. ${ }^{9}$

\section{Kesimpulan}

Pada penelitian ini kami mendapatkan bahwa diskrepansi nilai LED dan CRP pada fase akut PK cukup tinggi. Oleh sebab itu, kedua reaktan fase akut ini sebaiknya diperiksa bersamaan untuk menunjang diagnosis awal.

\section{Ucapan terima kasih}

Penulis mengucapkan terima kasih kepada Prof. Dr. dr. Sudigdo Sastroasmoro, Sp.A(K) atas bantuannya dalam pembahasan penelitian ini.

\section{Daftar pustaka}

1. Tremoulet AH, Jain S, Chandrasekar D, Sun X, Sato Y, Burns JC. Evolution of laboratory values in patients with Kawasaki Disease. Pediatr Infect Dis J 2011;30:1022-6.
2. Anderson MS, Burns J, Treadwell TA, Pietra BA, Glodé MP. Erythrocyte sedimentation rate and C-reactive protein discrepancy and high prevalence of coronary artery abnormalities in Kawasaki disease. Pediatr Infect Dis J 2001;20:698-702.

3. Newburger JW, Takahashi M, Gerber MA, Gewitz MH, Tani LY, Burns JC, dkk. Diagnosis, treatment, and longterm management of Kawasaki disease: A statement for health professionals from the committee on rheumatic fever, endocarditis and Kawasaki disease, council on cardiovascular disease in the young, American Heart Association. Circulation 2004; 110:2747-71.

4. McCrindle BW, Rowley AH, Newburger JW, Burns JC, Bolger AF, Gewitz M, dkk. Diagnosis, treatment, and long-term management of Kawasaki disease: A scientific statement for health professionals from the American Heart Association. Circulation. 2017;CIR.0000000000000484.

5. Batlivala SP. Focus on diagnosis: the erythrocyte sedimentation rate and the C-reactive protein test. Pediatr Rev 2009;30:72-4

6. Lee K-Y, Han J-W, Hong J-H, Lee H-S, Lee J-S, Whang K-T. Inflammatory processes in Kawasaki disease reach their peak at the sixth day of fever onset: laboratory profiles according to duration of fever. J Korean Med Sci 2004;19:501-4.

7. Litao MKS, Kamat D. Erythrocyte sedimentation rate and C-reactive protein: How best to use them in clinical practice. Pediatr Ann 2014;43:417-20.

8. Xiu-Yu S, Jia-Yu H, Qiang H, Shu-Hui D. Platelet count and erythrocyte sedimentation rate are good predictors of Kawasaki disease: ROC analysis. J Clin Lab Anal 2010;24:385-8.

9. Lee K-Y, Rhim J-W, Kang J-H. Kawasaki disease: Laboratory findings and an immunopathogenesis on the premise of a "protein homeostasis system." Yonsei Med J 2012;53:262-75.

10. Lee K-Y, Lee H-S, Hong J-H, Han J-W, Lee J-S. Highdose intravenous immunoglobulin downregulates the activated levels of inflammatory indices except erythrocyte sedimentation rate in acute stage of Kawasaki Disease. J Trop Pediatr 2005;51:98-101.

11. Advani N. Penyakit Kawasaki: faktor risiko risiko terjadinya aneurisme koroner, perjalanan klinisnya serta jumlah dan kualitas sel progenitor endotel, disertasi. Jakarta: Fakultas Kedokteran Universitas Indonesia, 2014. 